\title{
Pinkes Szczekocin. Księga Pamięci Szczekocin (Życie i zagłada żydowskiego miasteczka), red. Isroel Szwajcer (Ben-Awrom), Wydawnictwo Ziomkostwa Szczekocinian w Izraelu, Tel Awiw [5]720-1959; wydanie polskie: Pinkes Szczekocin. Księga Pamięci Szczekocin (Życie i zagłada żydowskiego miasteczka), red. wyd. pol. Mirosław Skrzypczyk, Marek Tuszewicki, Anna Wieczorek, przeł. z jidysz i hebrajskiego Marek Tuszewicki, Szczekociny 2010
}

Izkor bicher - ksiąg pamięci żydowskich miast i miasteczek Europy Środkowo-Wschodniej postało po wojnie kilkaset. Księgi te ocaleni spisywali w hołdzie pomordowanym, a ku przestrodze żywym. Skupieni w amerykańskich, australijskich czy izraelskich ziomkostwach, podsumowywali żydowskie dzieje dawnych domowych ojczyzn. Spisując historię poszczególnych miejsc, najczęściej mieli poczucie ostatecznego jej zamknięcia. Nie wierzyli w to, że kontynuacja przedwojennego i w ogóle jakiegokolwiek - życia żydowskiego w Europie, a szczególnie w Polsce, będzie możliwa. Księgi stały się pożegnaniem z europejską częścią historii Żydów, żałobą po jej tragicznym finale - Zagładzie, oraz symbolicznym nagrobkiem jej ofiar. Z różnorakich przyczyn przez wiele lat nie sięgano do nich ani w Polsce, ani na świecie. Kiedy wreszcie zaczęto się nimi interesować, okazało się, że już niewielu badaczy i amatorów historii Żydów włada jidysz, językiem, w którym spisano zdecydowaną większość izkor bicher. W ostatnich latach w sukurs przyszły im przekłady, przede wszystkim anglosaskie.

W Polsce przełożono do tej pory trzy księgi: Chorzeli ${ }^{1}$, Biłgoraja ${ }^{2}$ i Szczekocin. Najnowsza, szczekocińska ukazała się w 2010 roku. Inicjatorami jej wydania byli ze strony polskiej - Mirosław Skrzypczyk, nauczyciel i miłośnik lokalnej historii, oraz - ze strony izraelskiej - Yossi Bornstein, przewodniczący Organizacji Żydów Szczekocińskich.

Ta międzynarodowa współpraca wydaje się unikatowa. Rzadko się dziś zdarza, by zrzeszające zazwyczaj bardzo już wiekowych ludzi ziomkostwa oficjalnie włączały się w projekty związane z Polską i w Polsce realizowane. Yossi Bornstein nie chce poprzestać na tłumaczeniu Pinkes Szczekocin. W przyszłości pragnie stworzyć muzeum miasteczka. Powstanie ono w Izraelu, by mieszkającym tam Żydom przekazywało pamięć o bardzo ważnym, polskim fragmencie ich historii.

${ }^{1}$ Księga pamięci Żydów chorzelskich / Komitet Ziomkostwa Chorzelskiego w Izraelu; przedm. Sz. Weiss; [tłum. Adam Bielecki], Jerozolima - Holon 2006.

${ }^{2}$ Zagłada Biłgoraja. Księga Pamięci, red. M. Adamczyk-Garbowska, A. Trzciński, Sopot 2009. 
Tymczasem przełożona właśnie szczekocińska księga ma szansę przypomnieć Polakom o trwającej stulecia żydowskiej obecności w naszym kraju. Ta pożyteczna lektura została bardzo starannie i kompetentnie przetłumaczona z jidysz i hebrajskiego przez Marka Tuszewickiego, który w obszernym Wprowadzeniu do przekła$d u$ przedstawił historię gatunku oraz wyłożył czytelnikowi zasady translatorskie swej pracy. Sporządził też Stowniczek terminów judaistycznych. Książka zaopatrzona jest w indeks osobowy i miejscowy.

Monika Polit 